\section{Teaching generality}

A proposal to broaden the British school curriculum is also a chance for the university system.

FIFTEEN years ago, the British educational establishment was bitterly divided by a proposal for the reform of school-leaving examinations. Recognizing that students planning to stay on in higher education were too often required to rehearse in advance the studies they would later follow at university, and that the consequence was often a lopsided education, many school teachers and some university teachers took up the cause of a broadening pattern of school-leaving examinations under the banner N (for "normal") and F (for "further"). The idea was that instead of spending their last two years of secondary education following courses as narrow in pattern as chemistry, physics and mathematics, or even Latin, Greek and ancient history, students would be able to study more broadly, perhaps bridging the longstanding gap between the physical and biological sciences or even acquiring some skill with foreign languages.

In the event, years of planning came to nothing, chiefly because of the universities' fears that their students would be too illequipped with specialist knowledge to gallop through the standard three-year degree course. Hence the surprise that Sir Keith Joseph, the Secretary of State for Education and Science, should last week have floated a rather similar notion, for schoolleaving examinations called A (for "advanced") and S (for "supplementary").

The fierce arguments of the early 1970s are unlikely on this occasion to be resuscitated. In the interval, most of those concerned have been convinced that the peculiarly English pattern of secondary education to which intending university students are subjected is indeed too specialized. Secondary schools, increasingly concerned with the needs of students for whom there will be no room at university, have come to appreciate the absurdity of simulating for their academically-inclined students teaching which is more appropriate for the introductory part of a university course, while many of the students concerned have chosen to opt out, quitting their secondary schools in favour of other establishments with a more adult flavour, called colleges of higher education.

Scottish educationalists have been amused by this change of heart in the rest of the United Kingdom, knowing that they have for the past century operated a perfectly sound educational system not flawed by early and narrow specialization (but requiring that students should spend four years acquiring a first degree). One of the reasons why English universities have come round to the same way of thinking is the simple arithmetical calculation that the reduction in the scale of their activities decreed by the British Government would be neatly offset by the replacement of the most common pattern of three-year degree courses with the four-year pattern which is universal in Scotland (not to mention the United States and most places in Western Europe). This is what many universities have been telling the University Grants Committee in the past few weeks. The government's proposals on school-leaving examinations is in this connection a kind of advance counter-proposal - generality without the extra cost of longer university courses.

The danger now is that the discussion of the new examinations will be conducted on too narrow a front. The ideal is that it should be informed by a proper understanding of what secondary schooling is for. For too long (except in Scotland), British schools have been hamstrung by the need to cater both for the generality of their students and for the needs of those with academic inclinations. The system worked well enough, but inequitably, when the majority of students were invited to leave school at a tender age. Now that people must stay at school at least until sixteen, and while the shortage of jobs in the real world implies that young people stay on at school for longer than in the old days, the only respectable goal of secondary education is what it should have been in the first place - the provision for young people of an intellectual foundation on which adult skills may be founded.
British higher education, and the universities in particular, have a more awkward problem to solve. In 1970, it would have been possible to arrange for a coordinated change in the division of responsibility between the schools and higher education; now the schools are changing anyway, and new examinations will speed the process along. This time, however, the universities will have less influence than they might have had, and will lack the resources necessary to extend the bulk of their undergraduate teaching from three years to four. The way out of this dilemma is simple enough - the University Grants Committee, nearing the point at which it will have to decide how to shape the future of the British university system, should encourage one or two of them to become four-year institutions that select students a year earlier than now and possibly by means of criteria different even from the new school-leaving examinations. The system is much in need of diversity. This is merely one of the several ways in which it should be provided.

\section{Too many paymasters}

The British Government's sale of its telecommunications monopoly highlights conflicting interests.

How do you best arrange to sell a monopoly business as a going concern? By doing everything you can to ensure the monopoly is intact, for then the bidders will pay a higher price. That is plainly the thinking underlying the British Government's announcement last week of the terms on which it will sell at least 51 per cent of its holding in the telecommunications service now called British Telecom. The intention is that the service will be converted into a public company of the ordinary kind, and that shares will then be sold to whoever will buy them at a price still to be decided. Most probably, all this will happen in the autumn of this year. For political reasons, especially so as to demonstrate that its policy of shedding nationalized industries is justifiable, the government is anxious that the sale of shares shall be a "success" - which will probably mean that the price will be pitched low, or "generously" as the stockbrokers say. Even so, the hope is that something in excess of $£ 3,000$ million will help to swell the British Government's income in the current year.

This irreversible step is the last in a series of swings of policy on telecommunications in the past five years, although its roots go back to the time when, in the late 1960s, Mr Tony Benn (as he is now) decided that for administrative purposes, the British telecommunications service should be managed as if it were a private business. By the time of the present government, now just five years old, it had been concluded that the public monopoly's insistence on being the sole supplier of terminal equipment should be ended, with the result that there has since been a slow widening of the equipment available for use with telephone lines. At one time, the government was also inclined to think that the best way of bringing the monopoly to heel would be to license competitors, and one of these (called Mercury) now actually exists. But the view that British Telecom should be sold on the stock exchange has put a stop to such diversions, while the disputes that persist between the monopoly and private companies supplying radio-paging and cellular radio services are unlikely to be settled until after the monopoly has been sold.

The pity is that there has never been a convincing case that selling British Telecom as a going concern would better serve the public interest than, say, breaking it into smaller pieces (as in the United States) or reducing its activities to the installation and maintenance of a network that people could then use as they chose (for a fair price). Nor, yet, has there been an informed debate about the terms of the licence under which the monopoly will be allowed to operate. Even the government's undertaking that for the next five years, the charge made by the monopoly for its services should be increased each year by less than the inflation rate less three per cent is meaningless: the government itself has been compelling British Telecom to finance its development costs from telephone charges when a public company would have been borrowing from the banks. 